
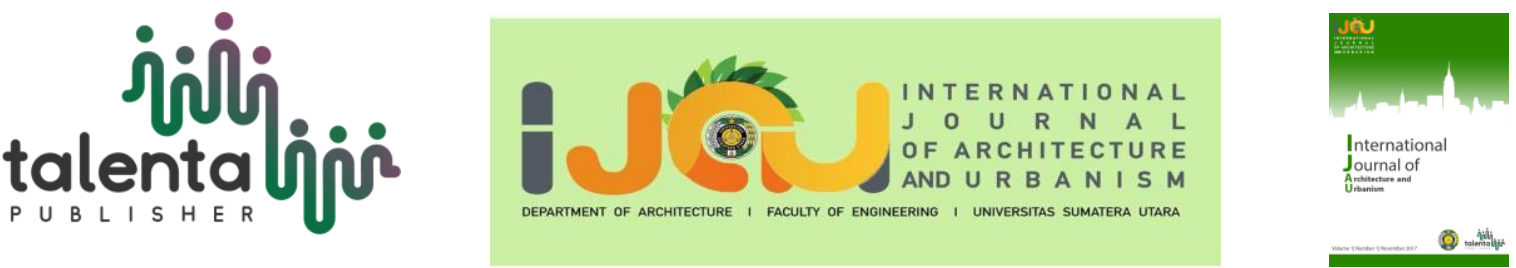

\title{
Median Road Revitalization as an Alternative Way to Overcome Flood on Jalan Asrama, Helvetia, Medan - Indonesia
}

\author{
Suryo Sukarno P. K. ${ }^{I^{*}}$, Luthfi Audi ${ }^{I}$, Muhammad Danesh ${ }^{1}$ \\ ${ }^{1}$ Department of Architecture, Universitas Panca Budi, Medan, North Sumatera, Indonesia
}

\begin{abstract}
Jalan Asrama, Helvetia Medan, is one of the areas in Medan that is often flooded. The puddle of water on Jalan Asrama, especially at the intersection of Gaperta Street, is already very alarming because the puddles that occur can reach heights of up to 0.5 meters so that it greatly disrupts traffic activity at that location. The cause is the inadequate condition of infrastructure facilities; one of the infrastructures referred to is the drainage and utilization of the Median Road that is not optimal. The purpose of this research is to find out the factors that cause flood inundation on the road bodies around Jalan AsramaMedan following offer a solution by revitalizing the median Road as one way to overcome the flood. The research method used descriptive qualitative research methods. Namely by conducting research directly into the field and conducting library studies on various types of reading material related to the object of study in this study, among others in the form of books, journals, articles, and written works in the form of print media and internet media. This study concludes that the occurrence of inundation in the bodies of roads around Jalan Asrama, Helvetia, is caused by several factors. First, high rainfall, the two dimensions of drainage channels are not suitable in some parts; third is sedimentation and rubbish, which reduce the dimensions of the channel and inhibit the flow rate of water. Moreover, one solution that can be done is to revitalize the median of the road, which hopes can overcome the flood.
\end{abstract}

Keyword: drainage, flood, inundation, median road

Received 10-07-2020 | Revised 21-07-2020 | Accepted 30-07-2020

\section{Introduction}

Medan, as the capital of North Sumatra Province, has a problem that is very poor water puddles.

Because during the rainy season, most of the highways in the city of Medan experience puddles, especially highways found in basin areas such as on Jalan Asrama, Helvetia, and other places where water cannot flow. Stagnant water on the road can cause a reduction in the area of the road that can be passed by vehicles, and this puddle of water can cause damage to the road,

*Corresponding author at: Corresponding author at: Department of Architecture, Faculty Sains and Technology, Universitas Panca Budi, Jalan Gatot Subroto Km. 4.5, Medan, Indonesia

E-mail address: mazyoyok@gmail.com

Copyright (C) 2020 Published by Talenta Publisher, 
which has the potential to form holes or basins that make the road uneven, so it is prone to accidents. Utilization of the median road as an alternative to flood prevention is often ignored by decision-makers and contractors in the field and is often planned as if it is not an important job. Whereas the median road and drainage works are difficult and complex jobs, requiring more money, energy, and time. Functionally, it is difficult for us to clearly distinguish between roads, median roads, drainage systems, and flood control. However, in practice, we can say that so far, only drainage on the roadside has handled excess water before entering large channels or rivers. We can use the median of the road to be able to reduce and drain excess water flow and drain into the drainage.

\section{Literature Review}

Flood

Rainwater that falls in an area must be immediately disposed of or flowed. For this purpose, channels must be made to collect rainwater flowing on the surface of the ground, such as on the road, for example, and flow it into the drainage channel [1]. The size of the reservoirs and drainage channels must be sufficient to drain the flow of water that comes from their respective stream areas. Culverts, rivers, and so on must be large enough to drain the channel's discharge. If the things mentioned above are not taken seriously and carried out, then the risk that will be faced is a flood inundation [2].

Flooding, some call it "Air Bah", the connotative for flood in Indonesian, is the event of the sinking of land (which is usually dry) due to increased water volume [3]. Flooding can also be caused by extreme discharges from a river, causing flooding. Sometimes flooding on the streets occurs due to the influence of the high river water discharge, or it can also be due to high rainfall [4].

Flood events are the result of human and natural interaction, both of which influence and influence one another [5]. The cause does not only involve nature, but also humans; also local and global. Thus the cause is not only a technical problem but also non-technical. The causes of flooding include [6]: (1) There is no innovation yet to utilize the median Road not only as a traffic lane, but also as a water absorption medium before being drained into the drainage channel; (2) The water channel that is not functioning properly, because many are blocked, closed, or used as home land so that the water flow becomes blocked or not smooth; (3) Land that has poor water absorption; (4) Increasingly the surface of the ground that is closed. Surface water system changes occur due to changes in natural color caused by settlements, industry, and agriculture; (5) High sedimentation, which causes rivers and trenches to become shallow; (6) High ground water level (flat area). The amount of rainfall exceeds the ability of the soil to 
absorb water, so that water flows on the surface; (7) Poor handling of municipal waste and inadequate surface water control infrastructure.

Median Road

The median road, according to the author, can not only be used as limiting the traffic lane but can also be used and revitalized to be able to drain excess water debit in the face of the road before it flows into the drainage channel or river. As for some of the understanding of the median Road are [7]: (1) The median road is a central part of the body of the road that physically separates the flow of traffic in the opposite direction; the median road (middle separator) can be in the form of a raised median, depressed median, or flush median [8]; (2) The median road is a physical divider of the traffic lane which functions to eliminate traffic conflicts from the opposite direction, which in turn will improve traffic safety.

The existence of the median road provides a harmony of the urban environment, means of safeguarding a comfortable, fresh, beautiful, and clean urban environment as well as creating an aesthetic that provides comfort and beautifies the urban environment on a micro-scale. The median road is planned to improve safety, smoothness, and comfort for road users and the environment [9]. The function of Median Road [10] are : (1) Separating the two opposite directions of traffic flow; (2) To block traffic turn right; (3) Waiting for booths for pedestrians; (4) Placement of facilities to reduce glare from vehicle headlights from the opposite direction; (5) Placement of road support facilities; (6) Lane reserves (if large enough); (7) Temporary work infrastructure; (8) In use as a green belt.

There are three types of median road [11], they are; (1) The Plain Median Road, which is a median bounded by two longitudinal markings of a solid line, the distance of two longitudinal markings of a solid line can be categorized as a median if the distance is $>18 \mathrm{~cm}$, inside it is equipped with oblique markers. The provisions on the use of markers as median road follow the guidelines for planning markings in force; (2) The Elevated Median Road, that is, the median that is made higher than the road surface. On the outside of the median must be equipped with a Kereb. The raised median must follow the stipulated median that is raised if the width of the land available for placement of the median is less than 5.0 meters and the median road height of the road surface is between $18 \mathrm{~cm}$ and $25 \mathrm{~cm}$; (3) The Lowered Median Road, that is the median road is made lower than the surface of the traffic lane. The installation of this median follows the following conditions: (a) The Median Road derived mounted if the width of the land provided to the median greater than or equal to 5.0 meters; (b) The Median Road surface slope is between $6-15 \%$, starting from the outside to the middle of the median and physically shaped in the basin; (c) The Median Road surface is not hardened and can be given material that can reduce the speed of a vehicle that is out of control. 
In the Guidelines for Construction and Building Median Road Planning (2004) there are 7 (seven) aspects that must be met in terms of the median planning, they are safety aspects, geometric aspects, smooth aspects, comfort aspects, efficiency/ economic aspects, aspects of road drainage, and aspects pedestrian [12]. In addition to maintaining other aspects, this research will maximize the median aspects of the road in the planning by making a median road that does not become a barrier to the flow of road surface water, and if needed in the median area, can be used open or closed drainage so that the purpose of this research is to be able to control flooding through updating the design of the median road that can be fulfilled [13].

\section{Methodology}

The method in this study uses a descriptive qualitative research method that can be interpreted as a research method that emphasizes deep involvement with site-specific settings, especially through active and thorough observation.

The study focused on the Jalan Asrama section from the intersection of Jalan Gatot Subroto to the intersection of Jalan Gaperta. The selection of this research location is based on road conditions that are prone to flooding when heavy rain occurs with high water discharge.

The type of data obtained in this study is (1) Primary data, i.e., data obtained in the field through the results of observations and direct observations of road conditions, drainage and median Road conditions that are now applied in Jalan Asrama; (2) Secondary data, i.e., data obtained from literature studies on various types of reading material related to the object of study in this study include books, journals, articles and written works in the form of print media and internet media.

Analysis of the data needed in this research is to use qualitative descriptive analysis, which results can be in the form of empirical data. Where researchers describe data and theories as consideration for obtaining results from research. Also, researchers have never separated from the literature as a source of research. The research here is used to obtain a flood disaster management strategy by revitalizing the median Road to become a water catchment where so far, the median road has only functioned as a limiting road flow.

\section{$4 \quad$ Analysis and Discussion}

Site Analysis

High rainfall in the city of Medan with an average rainfall per month from 18.75 to $216.33 \mathrm{~mm}$, which results in high water discharge, often causes puddles in almost all cities in Medan. During the rainy season, most of the highways in the city of Medan suffer from standing water, 
especially highways found in basin areas such as the Asrama, Helvetia, and other places where water cannot flow (Table 1).

Table 1 Rainfall Intensity Parameters

\begin{tabular}{llcc}
\hline \multirow{2}{*}{ No } & \multirow{2}{*}{ Kategori } & \multicolumn{2}{c}{ Rainfall Intensity } \\
\cline { 3 - 4 } & & Hourly $\mathbf{( m m} / \mathbf{h r})$ & Daily $\mathbf{( m m} / \mathbf{h r})$ \\
\hline 1 & No Rain $($ Cloudy) & - & - \\
\hline 2 & Light rain & $0.1-0.9$ & $0.1-19.9$ \\
\hline 3 & Moderate rain & $5.0-9.9$ & $20.0-49.9$ \\
\hline 4 & Heavy Rain & $10.0-20$ & $50.0-100$ \\
\hline 5 & Very Heavy Rain & $>20.0$ & $>100.0$ \\
\hline
\end{tabular}

(Source: BMKG Medan)

Stagnant water on the road can cause a reduction in the area of the road that can be passed by vehicles. As a result, vehicles that pass through these road sections are forced to take turns passing through remaining roads that are not flooded, which can cause long traffic jams. The puddle of water on Jalan Asrama, especially at the intersection of Jalan Gaperta, is already very alarming because the puddles that occur can reach heights of up to 0.5 meters, making it very disruptive to traffic activity at these locations.

The cause is the inadequate condition of infrastructure facilities; one of the means referred to is the inadequate drainage and utilization of the median road. Under these conditions, research is needed to evaluate and determine efforts to deal with the problem of standing water/flood in the city of Medan, especially on Jalan Asrama, Helvetia Medan, by revitalizing the median Road as one way to overcome the flood problem that has been haunts the city of Medan (Figure 1).

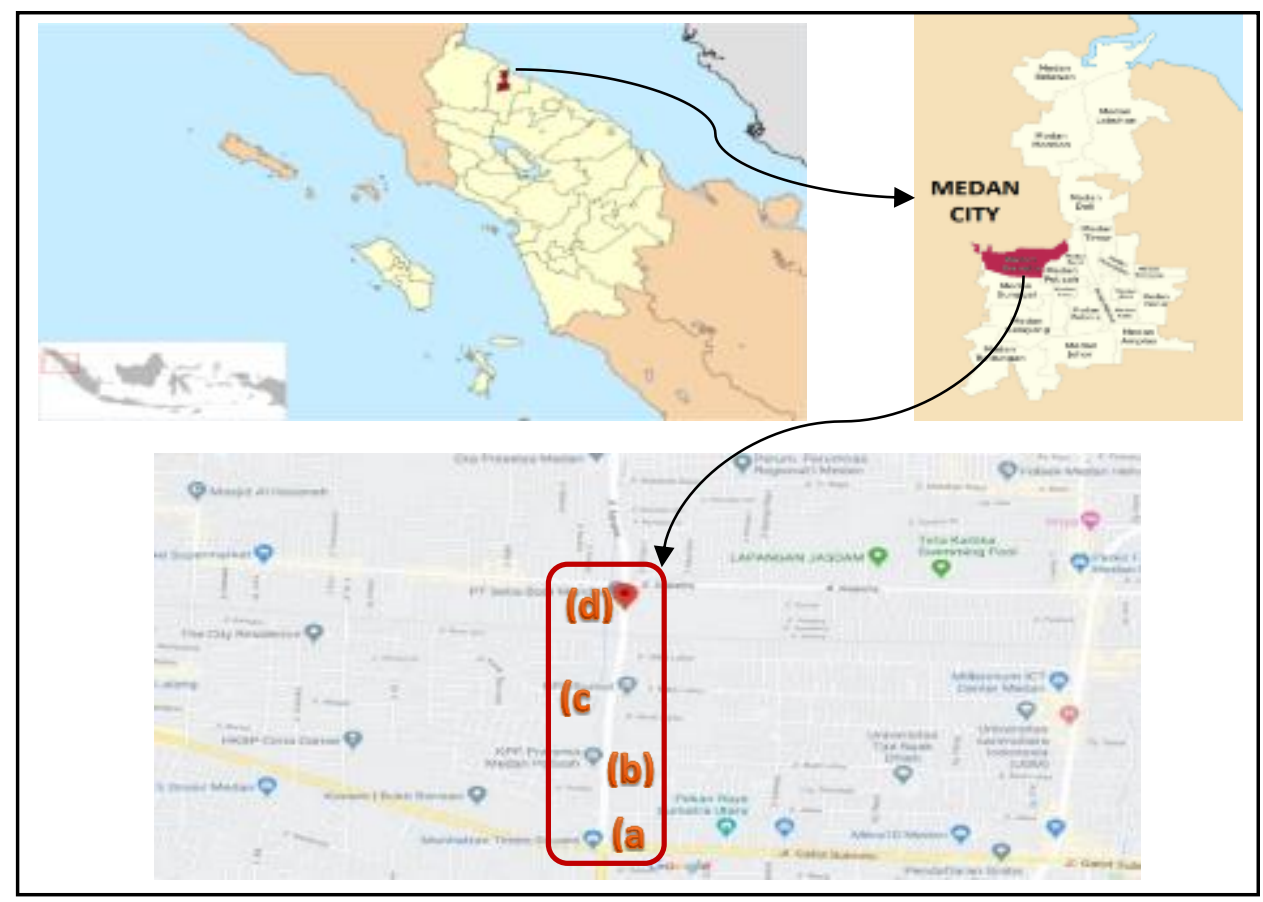

Figure 1 Location of Research Area, Jalan Asrama, Helvetia - Medan 
So far, the absorption of surface water on the main roads in the city of Medan has largely relied on drainages located on the left and right sides of the road. The existence of those drainages, if properly managed, will be very able to help drain water for the road. However, due to sedimentation, clogging, and not properly managed, these drainages often become shallow, clogged, and unable to accommodate and drain surface water on the highway (Figure 2-3).

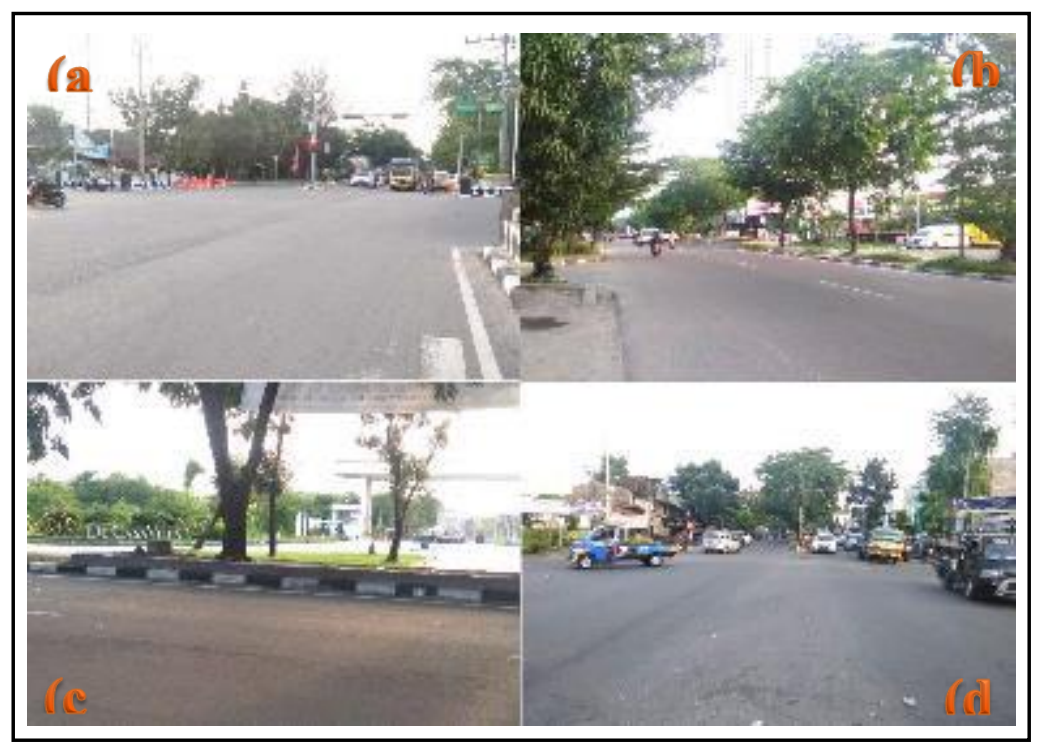

Figure 2 The condition of the location of the Median Road is reviewed starting from the Manhattan Mall intersection (a) - the road from Manhattan to Jalan Asrama (b) - the road in front of the De CasaVilla complex (c) - Jalan Gaperta Intersection (d)

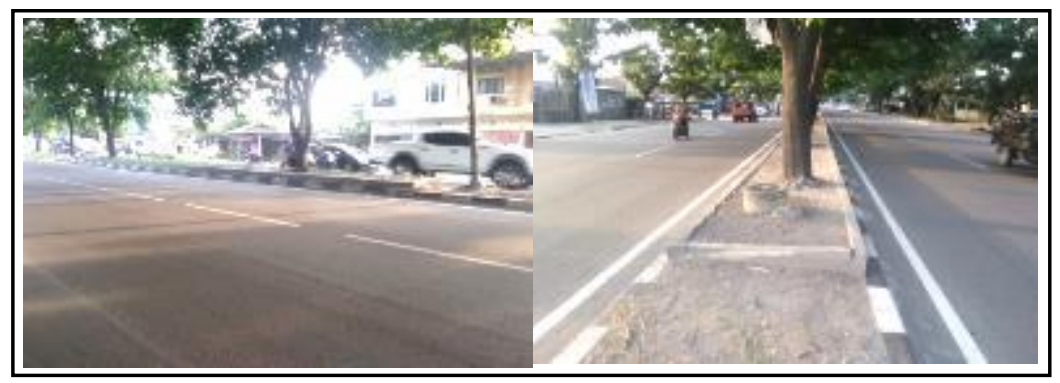

Figure 3 Types of Median Road Applied on Jalan Asrama, Medan

Therefore, the author, in this case, would like to utilize/ revitalize the median road (Figure 4), which has so far only served to restrict the middle of the road, becoming a medium to assist the absorption of surface water on the road while simultaneously flowing it into the drainage canal so that it can help and overcome the problem of flooding which has been a scourge on the main roads in the city of Medan.

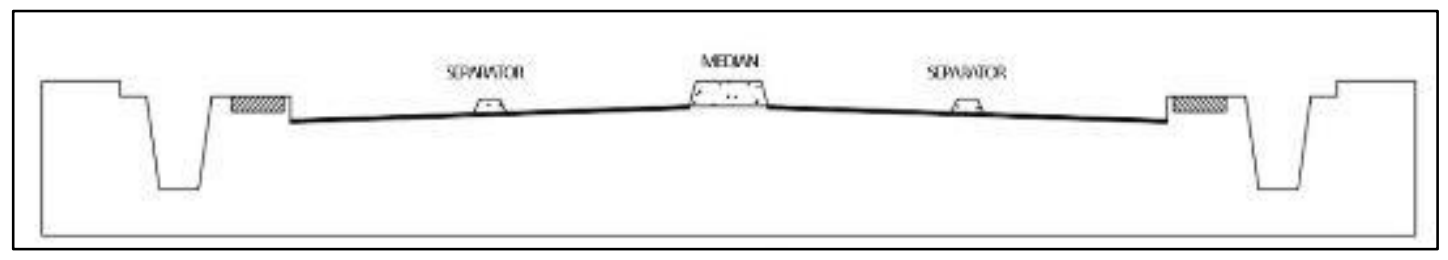

Figure 4 Typical Road Section with Mid-Road Roadster 
The type of median of the road adopted at Jalan Asrama, Medan is the type of median that is elevated, that is, the median is made higher than the road surface. On the outside of the median road must be equipped with a Kereb/Cansteen. Median with this type is quite significant when used for dividing road sections, but tends to be minimal for surface water absorption. This is because the median is made higher than the road, so water that stagnates on the road cannot be absorbed by the median of the road. So if you look at the field conditions documented in the flood event on May 29, 2019, in Medan Tribune media, we can see that the median road is not a means that can help flood water absorption (Figure 5).

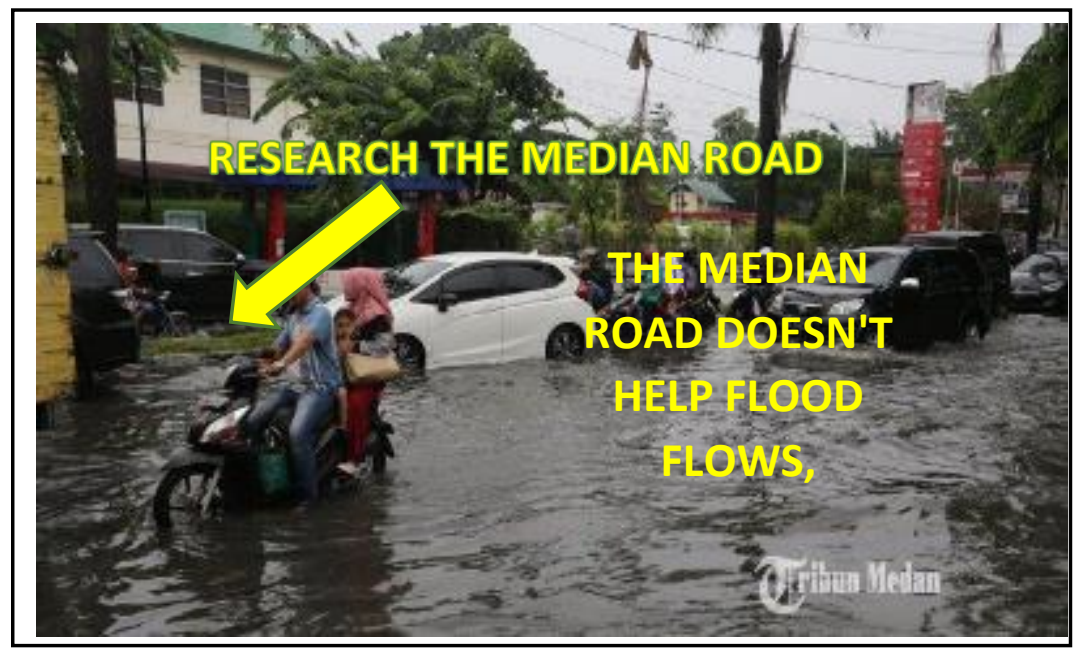

Figure 5 Analysis of the Median Road Type Applied on Jalan Asrama, Medan

(Source: Medan Tribune, 27 May 2019)

\section{Median Road Design Concepts}

There are several types of the median road, according to the Road Building Median Construction and Building Guidelines (2004) can be categorized into three types, which can be seen in Figure 6- 8.

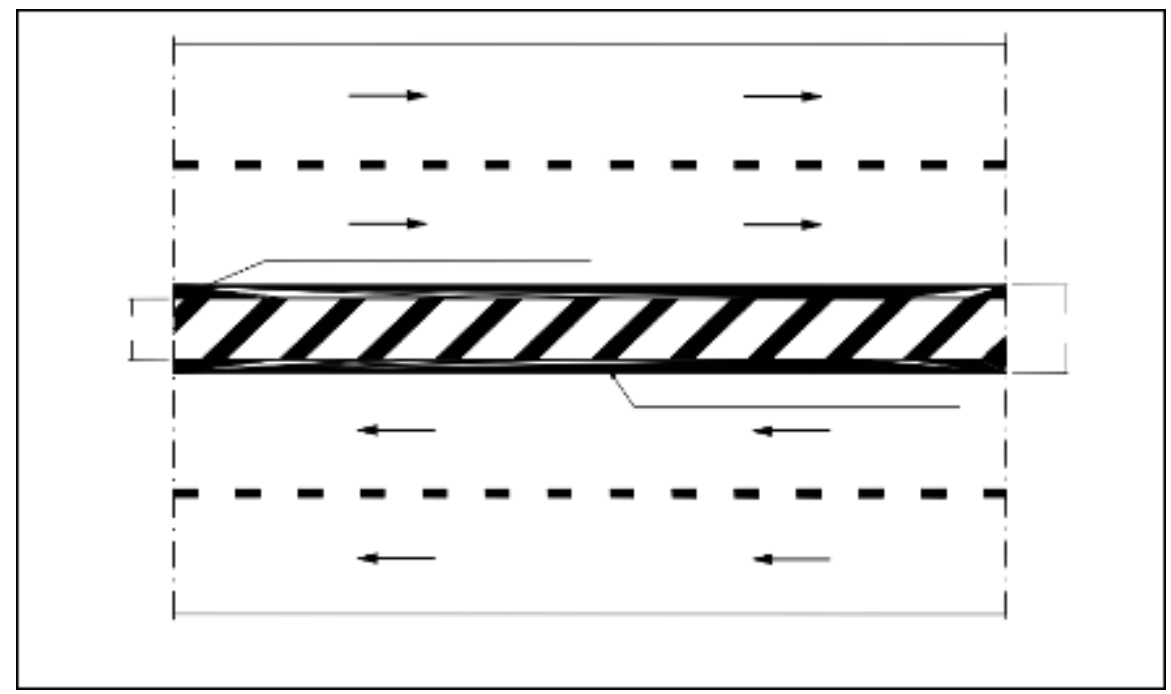

Figure 6 Flat Median Road Type 


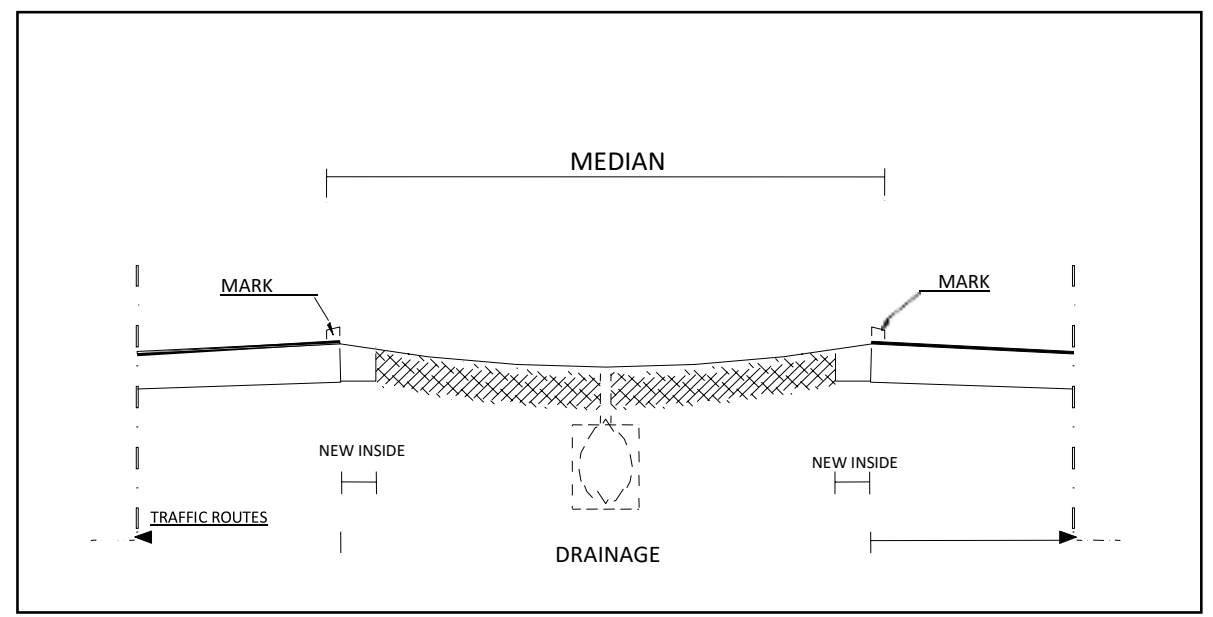

Figure 7 Lowered Median Type

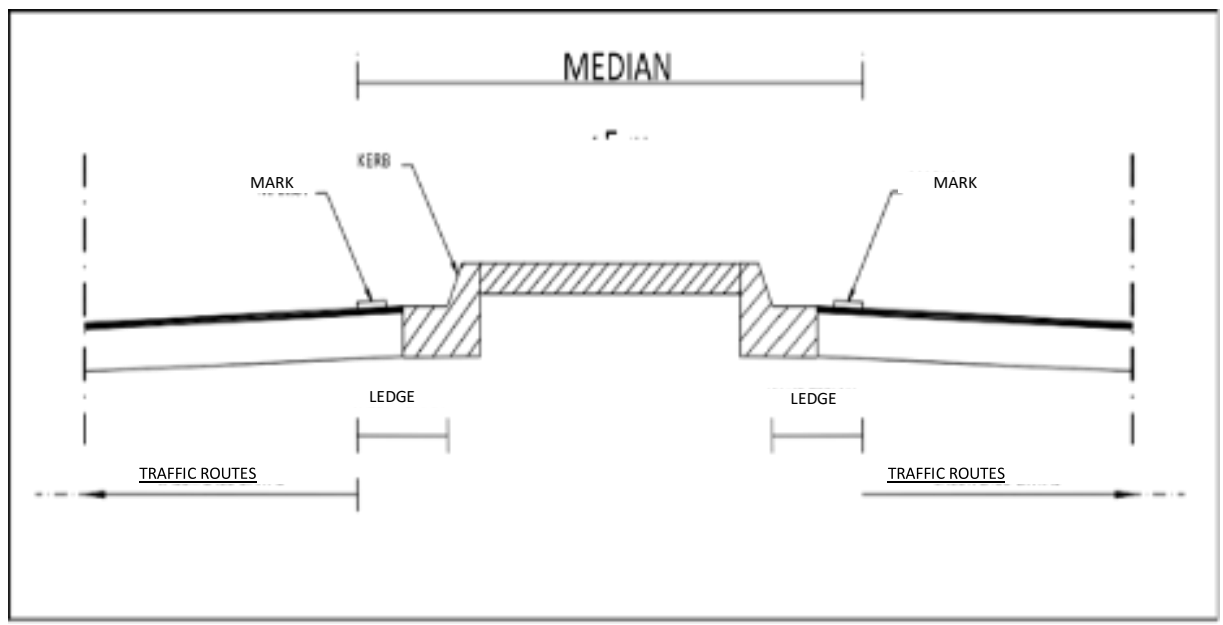

Figure 8 Elevated Median Type

Creating a new median Road design solution in the context of revitalizing the median Road in the Jalan Asrama area, Helvetia is very necessary so that it can add to the function of the median Road as flood control. The formation of the median Road will be very influential in responding to this.

Each median Road has advantages and disadvantages in their respective formations, so that of the three types in general, the shape design adopted by the author is a combination of the inherited and elevated median types, as well as the advantages and disadvantages of the median in Table 2 and Figure 9. So that the two median formations will be taken parts that are the strengths of each so that the new design formation will be the maximum design solution that can control flooding. 
Table 2 Advantages and disadvantages of Increased and Decreased Road Medication Types

\begin{tabular}{|c|c|c|c|}
\hline \multirow{2}{*}{ No } & \multirow{2}{*}{ Median Road Types } & \multicolumn{2}{|c|}{ Functions } \\
\hline & & Advantages & Dis-advantages \\
\hline \multirow[t]{2}{*}{1} & \multirow{2}{*}{$\begin{array}{l}\text { Types of Road } \\
\text { Elevated Medians }\end{array}$} & $\begin{array}{l}\text { The function of the road } \\
\text { separator is stronger, so it can } \\
\text { reduce the number of } \\
\text { accidents }\end{array}$ & $\begin{array}{l}\text { Cansteen or elevated } \\
\text { boundaries prevent water } \\
\text { flow from absorbing well } \\
\text { into the infiltration soil }\end{array}$ \\
\hline & & & $\begin{array}{l}\text { The infiltration soil that is on } \\
\text { the media of hard road tends } \\
\text { to inhibit water absorption }\end{array}$ \\
\hline \multirow{2}{*}{2} & \multirow{2}{*}{$\begin{array}{l}\text { Types of Road } \\
\text { Lowered Medians }\end{array}$} & $\begin{array}{l}\text { Do not block the waterway if } \\
\text { there is rain to the infiltration } \\
\text { ground at the median of the } \\
\text { road }\end{array}$ & $\begin{array}{l}\text { Do not have enough barriers } \\
\text { so that traffic accidents are } \\
\text { prone to occur }\end{array}$ \\
\hline & & $\begin{array}{l}\text { With the form of soil } \\
\text { infiltration that is lowered } \\
\text { down will accelerate the } \\
\text { process of water absorption }\end{array}$ & \\
\hline
\end{tabular}

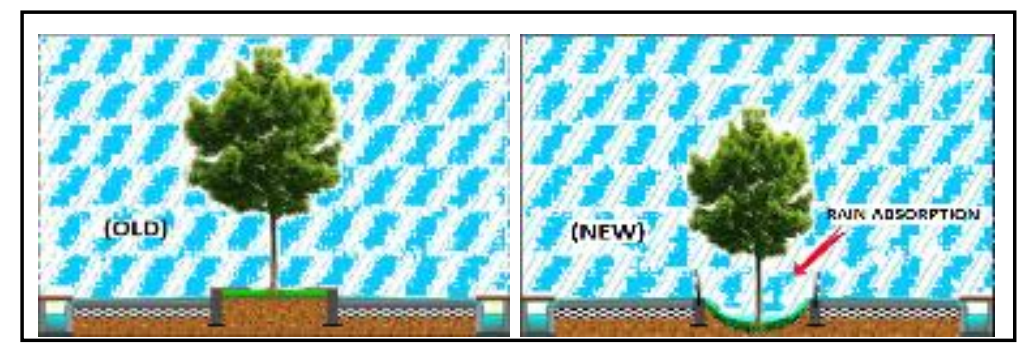

Figure 9 Illustration of Concept (Old) and Concept (new) Forming Median Road Applied on Jalan Asrama, Medan

Infiltration Wells and Biopores

Infiltration wells can be regarded as a water conservation engineering, in the form of buildings made in such a way that they resemble the shape of dug wells with a certain depth. The main function of this infiltration well is as a place to collect rainwater and absorb it through layers of fibers/ geotextiles and rocks into the soil (Figure 10).

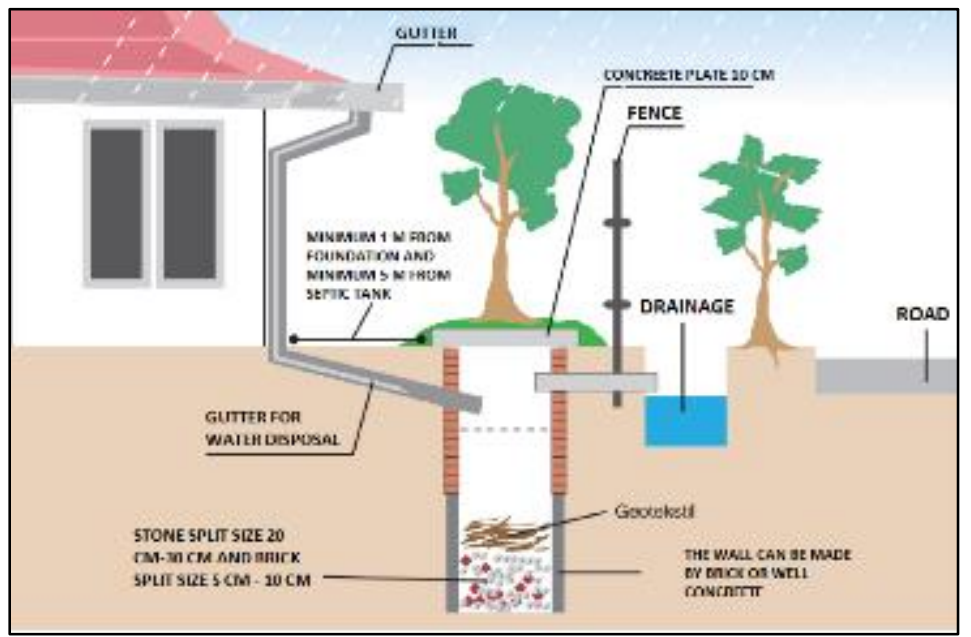

Figure 10 Basic Concept of Infiltration Well 
Biopores are cylindrical holes that are made vertically into the ground. The pure bio hole functions as an infiltration hole and is made with the aim of overcoming puddles. The way it works is to increase the water's absorption capacity. Biopori is made by making a hole in the soil and stockpiling it using organic waste. The use of organic waste aims to produce compost. Also, organic waste used to pile up biopori pits is also useful for supporting soil fauna (Figure $11)$.

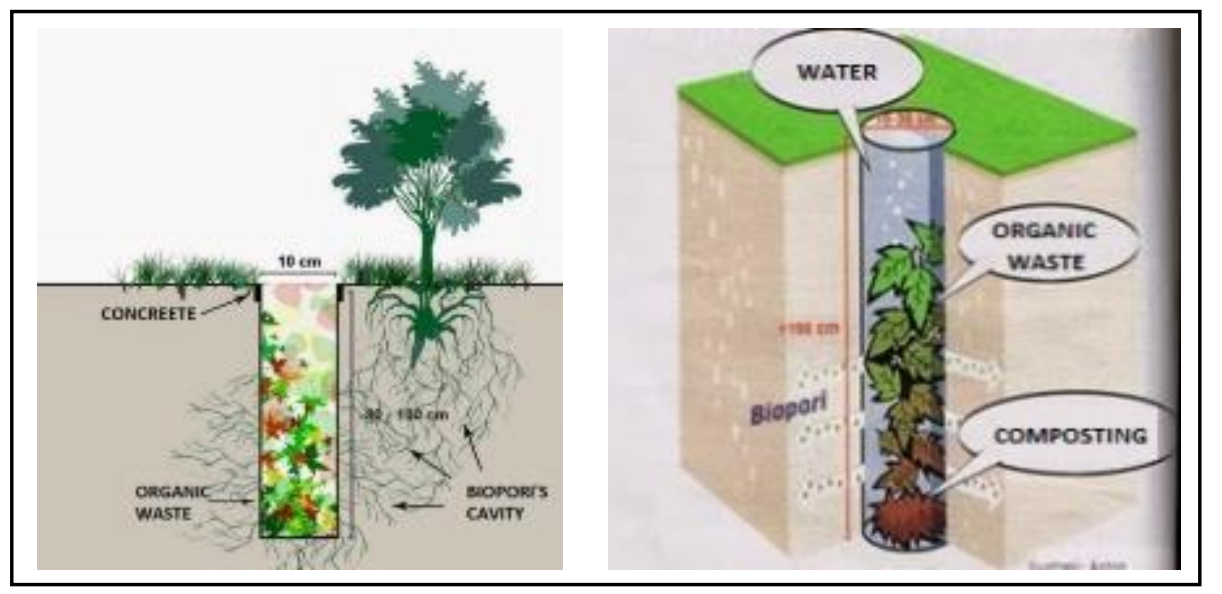

Figure 11 Basic Concepts of Biopori

The design of the concept of the solution offered by the author for the median Road in the Jalan Asrama, Helvetia, Medan-Indonesia area in particular, and Indonesia, in general, is a combination of the three things above, namely Median that is Lowered and Elevated, Infiltration Well and Biopori (Table 3 and Figure 12-15).

Table 3 Concept Design for Median Road on Jalan Asrama, Helvetia

\begin{tabular}{|c|c|c|c|}
\hline No. & Plan & Concepts & Application \\
\hline 1. & $\begin{array}{l}\text { The using of } \\
\text { Kereb/Cansteen } \\
\text { for the elevated } \\
\text { median road type }\end{array}$ & $\begin{array}{l}\text { - Make channel holes in the area } \\
\text { under the Kereb } \\
\text { - Make a filter at the kereb's } \\
\text { holes, so that the garbage does } \\
\text { not enter the median infiltration } \\
\text { ground }\end{array}$ & $\begin{array}{l}\text { - Kereb's Concrete } \\
\text { (Dimensions 40x15x25 cm) } \\
\text { - Holes, diameter } 10 \mathrm{~cm} \\
\text { - Strainer, bracing bar } \\
\text { diameter } 8 \mathrm{~mm}\end{array}$ \\
\hline 2. & $\begin{array}{lr}\begin{array}{l}\text { Lowered } \\
\text { median } \\
\text { land }\end{array} & \text { road's } \\
\end{array}$ & $\begin{array}{l}\text { - Deepen the excavation to the } \\
\text { underground, so that the } \\
\text { volume of soil to bind the } \\
\text { plants remains sufficient }\end{array}$ & $\begin{array}{l}\text { - The median soil is aligned } \\
\text { with the Kereb's base }\end{array}$ \\
\hline 3. & $\begin{array}{l}\text { Infiltration land's } \\
\text { layers as in } \\
\text { infiltration well }\end{array}$ & $\begin{array}{l}\text { - Make several layers filled with } \\
\text { different materials, so that more } \\
\text { water-binding material is then } \\
\text { passed on with pipes }\end{array}$ & $\begin{array}{l}\text { - Geotextile }(20 \mathrm{~cm}) \\
\text { - Fill Soil }(20 \mathrm{~cm}) \\
\text { - Japmat Filter }(4 \mathrm{~cm}) \\
\text { - Gravel }(20 \mathrm{~cm}) \\
\text { - Perforated Pipe (Dia 6" } \\
\text { Perforated Pipe) }\end{array}$ \\
\hline 4. & $\begin{array}{l}\text { The using of } \\
\text { Biopori's pipe }\end{array}$ & $\begin{array}{l}\text { - Plugging biopori's pipes in the } \\
\text { soil area to accelerate forward } \\
\text { water to the infiltration area } \\
\text { below }\end{array}$ & $\begin{array}{l}\text { - Bipori's Pipe (75 cm length } \\
\text { Perforated Pipe) }\end{array}$ \\
\hline
\end{tabular}

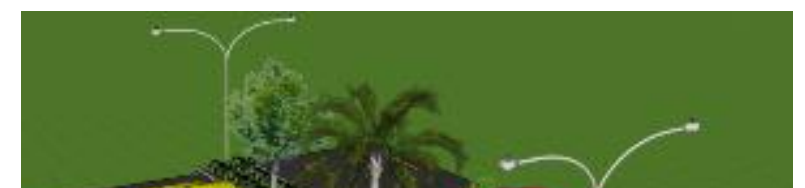


Figure 12 Perspective Concept Design Solution for Median Road on Jalan Asrama, Helvetia

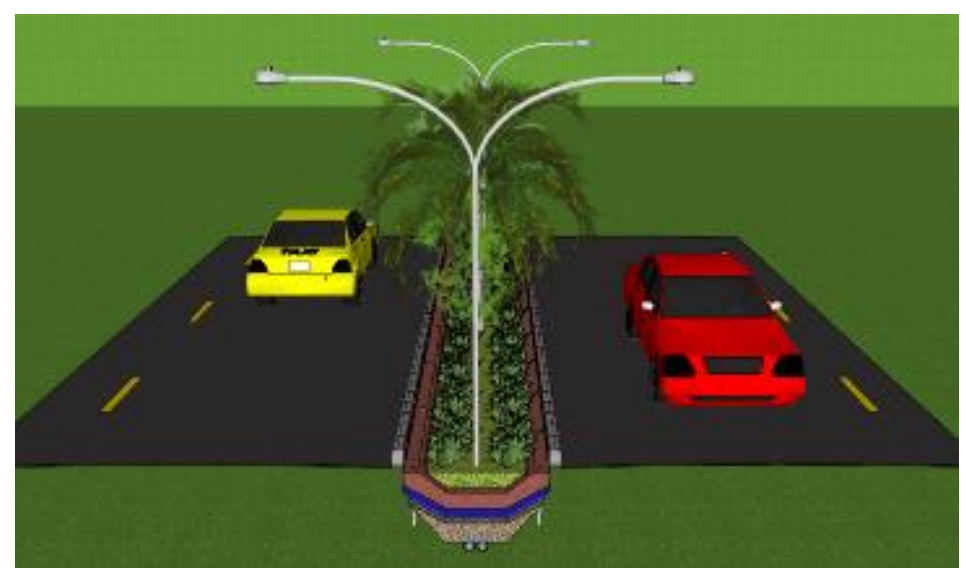

Figure 13 Front View Median Road on Jalan Asrama, Helvetia

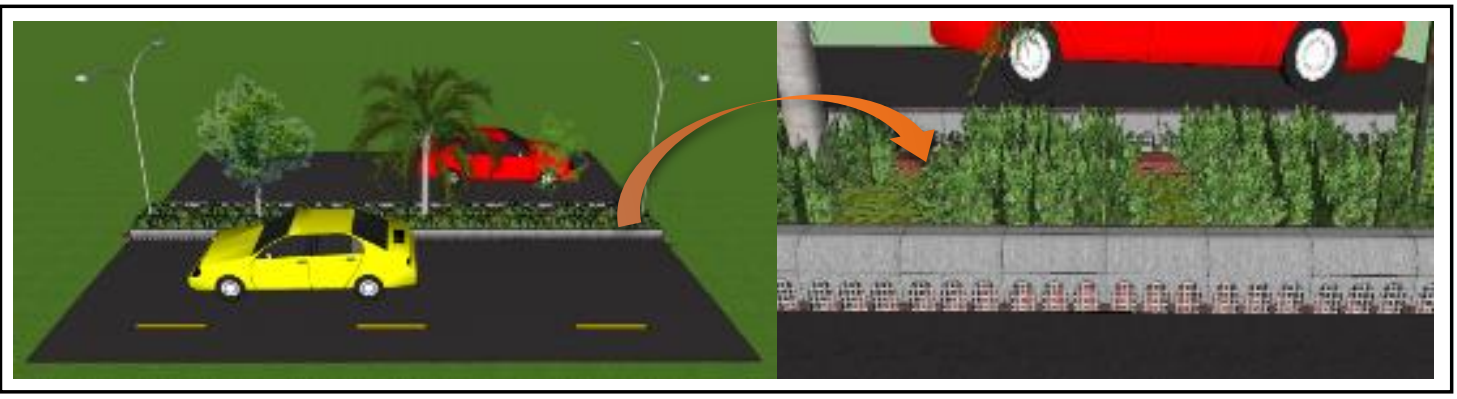

Figure 14 Side View Median Road on Jalan Asrama, Helvetia

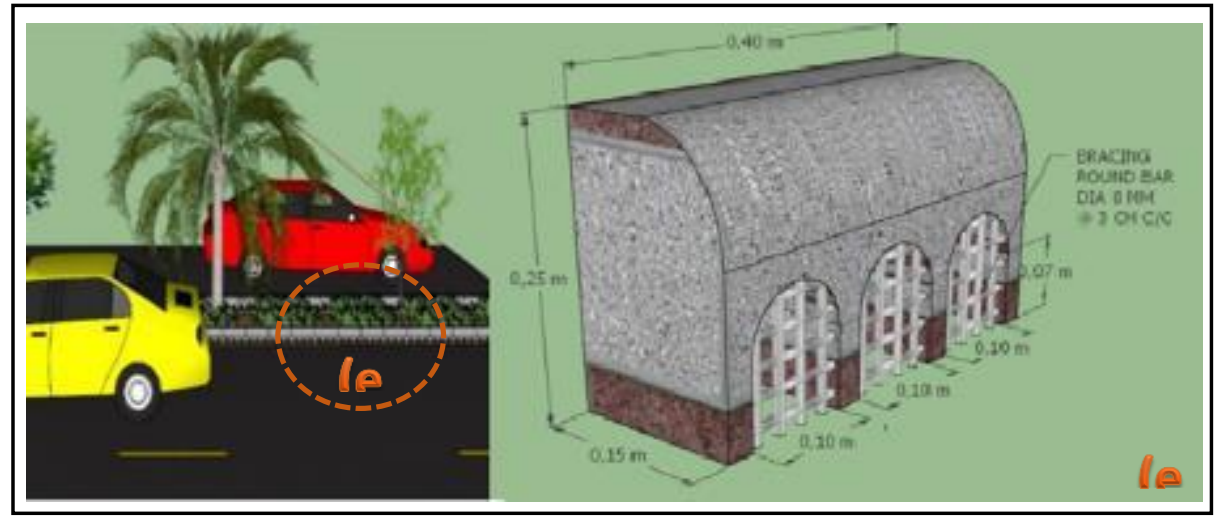

Figure 15 Detail Design of Kereb/Cansteen (e) Median Road on Jalan Asrama, Helvetia 
The use of Kereb/Cansteen is used to adopt the median type of elevated road while maintaining the boundary at the median of the road, the obstacle that will occur is that the waterway at the median edge will not be directly absorbed into the median recharge ground, so the solution is to provide holes in the Kereb design new equipped with iron bracing $8 \mathrm{~mm}$ in diameter per distance of $3 \mathrm{~cm}$ (for filtering dirt/ rubbish) so that the hole can be a waterway leading to infiltration soil (Figure 16 and 17).

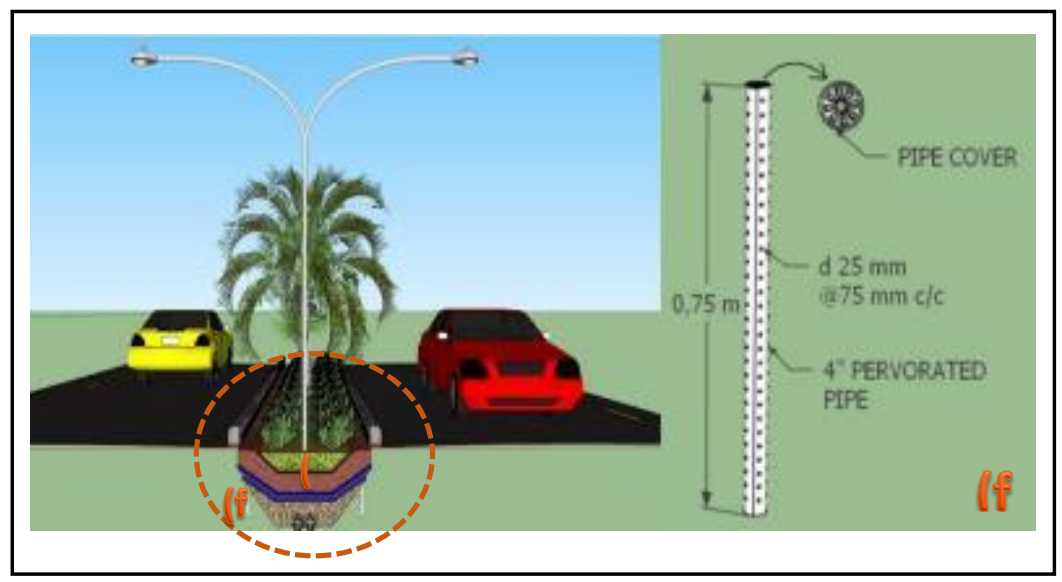

Figure 16 Detail Design of Biopori's Pipes (f) at Median Road on Jalan Asrama, Helvetia

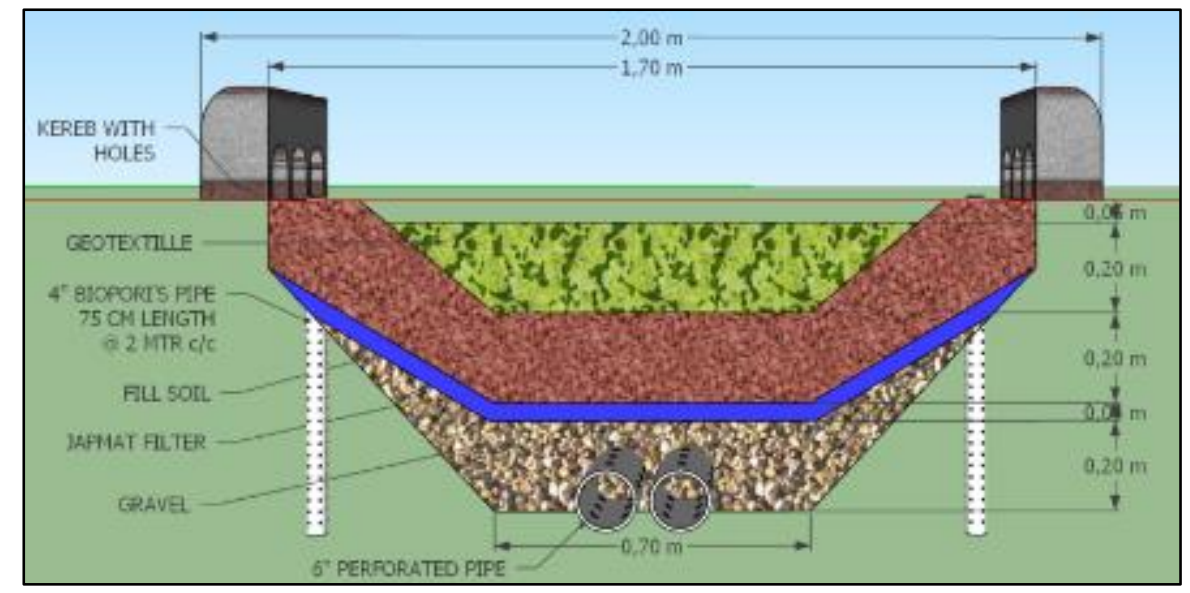

Figure 17 Details of Soil Infiltration at Median Road on Jalan Asrama, Helvetia

Water flowing from the Kereb goes directly to the infiltration soil, then in the infiltration soil there are layers that help the absorption to reach the drainage pipe which is in the last layer, and the biopori's pipe is also placed sticking from the upper layer to the soil underneath so that the spread of water also be optimal.

\section{Conclusion}

Design recommendations in terms of revitalizing the median of the road used as a way to deal with flooding on the highway. This design was made to provide suggestions for solutions for areas where the area being analyzed, namely in Jalan Asrama, Helvetia, Medan - Indonesia, and also is a suggested solution for the median of other roads in Medan in particular and in 
Indonesia in general for flood prevention on the highway. This design concept, according to the author, is also a long-term solution to help overcome the flood water that often floods the roads in major cities in Indonesia. This design solution does require a higher cost in the beginning. However, in the long run, it will be very useful for flood mitigation if implemented on protocol roads in major cities in Indonesia.

\section{Acknowledgment}

This research is part of the requirements to get the Final Semester IV Exam scores in the Department of Architecture, Faculty of Science and Technology, Universitas Panca Budi, Medan, North Sumatera, Indonesia.

\section{REFERENCES}

[1] D. I. Kusumastuti, D. Jokowinarno, S. N. Khotimah dan a. C. Dewi, "The Use of Infiltration Wells to Reduce the Impacts of Land Use Changes on Flood Peaks: An Indonesian Catchment Case Study," Pertanika Journal of Social Sciences and Humanities, vol. 25, no. 2, pp. 407-425, 2017.

[2] M. 1 Kahfi dan d. A. P. Mulia, "tudi Sistem Drainase Resapan Untuk Penanggulangan Banjir Di Lingkungan III, Pasar III, Padang Bulan Medan," Journal of USU Civil Engineering, vol. 3, no. 3, pp. 1-11, 2014.

[3] R. Mardin dan Z. \& Shen, "Integrated Criteria for Flood Disaster Mitigation in IndonesiaUrban Masterplan; Housing and Settlement Suitability Case in Palu Urban Masterplan," dalam Urban Planning and Water-related Disaster Management, Springer, Cham., 2019, pp. 127-153.

[4] J. J. Hutapea, "STUDI PENGARUH INTENSITAS HUJAN TERHADAP GENANGAN BANJIR DI BADAN JALAN (Studi Kasus di Sekitar Jalan Aksara-Medan)," Jurnal Teknik Sipil USU, vol. 2, no. 1, 2013.

[5] J. C. Aerts, W. J. Botzen, K. C. Clarke, S. L. Cutter, J. W. Hall, B. Merz dan H. \& Kunreuther, "Integrating human behaviour dynamics into flood disaster risk assessment," Nature Climate Change, vol. 8, no. 3, pp. 193-199, 2018.

[6] L. Gunderson, "cological and human community resilience in response to natural disasters," Ecology and society, vol. 15, no. 2, 2010.

[7] R. Tay dan A. \& Churchill, "Effect of different median barriers on traffic speed," Canadian Journal of Transportation, vol. 1, no. 1, 2007.

[8] [Online].

Available: https://binamarga.pu.go.id/v3/assets/files/NSPK/lingkungan_keselamatan_jalan/9.Prediks i\%20Kebisingan\%20Akibat\%20Lalu\%20Lintas.pdf.

[9] V. K. Sharma, S. Mondal dan A. \& Gupta, "nalysis of u-turning behaviour of vehicles at mid-block median opening in six lane urban road: A case study," International Journal for Traffic \& Transport Engineering, vol. 7, no. 2, pp. 243-255, 2017. 
[10] Construction and Building Guidelines Road Median Planning, 2004.

[11] D. Pamučar, L. Vasin, P. Atanasković dan M. \& Miličić, "Planning the city logistics terminal location by applying the green-median model and type-2 neurofuzzy network," Computational intelligence and neuroscience, vol. 2016, 2016.

[12] D. A. Belete, "Road and urban storm water drainage network integration in Addis Ababa: Addis Ketema Sub-city," Journal of Engineering and technology research, vol. 3, no. 7, pp. 217-225, 2011.

[13] Y. Hirabayashi, R. Mahendran, S. K. L. Koirala, D. Yamazaki, S. Watanabe dan S. \& Kanae, "Global flood risk under climate change," Nature Climate Change, vol. 9, no. 9, pp. 816-821, 2013. 